\title{
Jeanne-Henriette Louis, La Société religieuse des Amis
} (Quakers)

Turnhout, Brépols, coll. «Fils d'Abraham », 2005, 166 p.

Jean Séguy

\section{OpenEdition}

\section{Journals}

Édition électronique

URL : http://journals.openedition.org/assr/6672

DOI : $10.4000 /$ assr.6672

ISSN : $1777-5825$

Éditeur

Éditions de l'EHESS

Édition imprimée

Date de publication : 1 juin 2007

Pagination : $97-251$

ISBN : 978-2-7132-2143-9

ISSN : 0335-5985

\section{Référence électronique}

Jean Séguy, "Jeanne-Henriette Louis, La Société religieuse des Amis (Quakers) 》, Archives de sciences sociales des religions [En ligne], 138 | avril - juin 2007, document 138-60, mis en ligne le 12 septembre 2007, consulté le 21 septembre 2020. URL : http://journals.openedition.org/assr/6672 ; DOI : https:// doi.org/10.4000/assr.6672

Ce document a été généré automatiquement le 21 septembre 2020

(c) Archives de sciences sociales des religions 


\section{Jeanne-Henriette Louis, La Société religieuse des Amis (Quakers)}

Turnhout, Brépols, coll. « Fils d'Abraham », 2005, 166 p.

Jean Séguy

1 L'auteur de ce petit livre est une quakeresse française, professeur émérite (d'anglais et de sujets américains) de l'université d'Orléans. Précis, très clairement écrit, et agréablement illustré, cet ouvrage se compose de huit chapitres: 1 . Naissance et doctrine du mouvement quaker. 2. Histoire, où l'on apprend le devenir de l'héritage de George Fox (le fondateur, en plein Commonwealth cromwellien), à travers trois siècles et beaucoup de pays - les pays de langue anglaise viennent en tête, présentés selon les tendances (libéraux, évangéliques, conservateurs, New Foundation, universalists). 3. Organisation du mouvement (ce chapitre retiendra sûrement l'attention des sociologues). 4. Le quatrième chapitre présente une anthologie rapide (pp. 71-119) de textes jugés représentatifs de la foi et de la pratique quakers, textes traduits de l'anglais pour certains d'entre eux, allant du XVIII ${ }^{\mathrm{e}}$ siècle jusqu'à l'année 2004. 5. Le lecteur risque de marquer quelque étonnement devant un cinquième chapitre intitulé «Les quakers et l'art ", l'essentiel du « témoignage » quaker étant axé sur le silence (des cultes privés ou publics) et pointant la paix et le travail social au centre de l'agir des héritiers de Fox; de fait, on doit noter que l'attitude des Amis a varié, au cours des siècles, vis-à-vis de la beauté et de ses artisans (peintres, sculpteurs, musiciens, danseurs même, gens de théâtre et poètes) ; il y a beau temps que ces « expressifs de la beauté » ne sont plus des étrangers en milieu quaker. 6. Un profil sociologique (les statistiques comme éléments expressifs d'un avenir "post-moderne » autant que "post-chrétien») occupe(nt) le sixième chapitre. 7. La bibliographie (en français et en anglais). 8. Annexes variées (chiffres, tableaux, cartes), les pages 68-70 contenant des renseignements pratiques (adresses d'organismes internationaux et nationaux des Amis et les indications utiles concernant les «sites web» des mêmes. Ce chapitre de varia s'achève par ce qu'on pourrait appeler un exemple d'humour quaker: «il est rappelé que la compagnie "Quaker Oats" qui vend des céréales, n'est pas une entreprise quaker »... 
2 Soit pour s'initier, soit pour " aller plus loin », ce livret remarquablement informé est à ajouter au rayon «Religion » de toute bibliothèque de l'honnête homme, fût-il même sociologue. 